\title{
Causes of Non-Performing Loan: A Study on Bangladesh Public Sector Banks
}

\author{
A H M Yeaseen Chowdhury ${ }^{1 *}$, Afifatun Jannah ${ }^{2}$ \\ ${ }^{1}$ Former Associate Professor, Faculty of Business Studies, Bangladesh University of Professionals, Bangladesh \\ ${ }^{2}$ Intern at Shonali Bank Limited Bangladesh, Bangladesh \\ Email: yeaseenchy@bup.edu.bd
}

\begin{abstract}
This paper goes for surveying the reasons for non-performing credits in broad daylight division banks, particularly the reasons for nonperforming advances that identified with clients activities and bank tasks. It was guided by a study look into technique whereby discoveries from the considered example were summed up to the whole populace. The investigation test was 50 respondents includes 40 clients and 10 bank authorities. Clients were chosen by utilizing basic irregular testing where by each tenth client was incorporated into the example. Bank authorities were chosen utilizing accommodation inspecting methods. Information were gathered through meeting aide and questionnaire. The reasons for nonperforming credits identified with client activities were identified with moral dangers, deficient business, budgetary, promoting, enterprise and administration abilities, finance preoccupation and numerous advances. Also reasons for nonperforming credits identified with managing an account tasks were identified with unfavorable client choice issue, poor advance strategy, insufficient advance observing and recuperation, long line in saving money corridor, poor client administrations and debasements of bank officers. It prescribes that monetary organizations should join preparing of business, enterprise, money related administration and bookkeeping aptitudes. Money related foundation ought to likewise configuration fitting advance strategy that will lessen credit dangers, enhance advance checking and gathering.
\end{abstract}

Keywords: Non-performing loan (NPL), SMEs loans, SCBs, GDP.

\section{Introduction}

Every one of those unfriendly effect of NPLs on banks' money related wellbeing, for example, low gainfulness and low capital base are obviously reflected in Bangladesh keeping money segment. Be that as it may, the business banks of our nation (particularly the state possessed banks) are neglecting to do their consistent business exercises due to non-performing credits. The saving money industry particularly the business banks need to keep up a few principles and directions of Bank Company Act 1991 and time-to-time rules of Bangladesh Bank (Central Bank of Bangladesh).

In this paper, I display how to decide the genuine sum, reason for non-performing advances in our business banks, nonetheless, the business banks of our nation (particularly the state possessed banks) are neglecting to do their consistent business exercises due to non-performing credits. The managing an account industry particularly the business banks need to keep up a few standards and controls of Bank Company Act 1991 and time-to-time rules of Bangladesh Bank (Central Bank of Bangladesh).

\subsection{Objectives of Study}

General Objectives: The general objective of the study is to assess the causes of non-performing loans in Public sector banks of Bangladesh.

Specific Objectives: The specific objectives of the study are:

- To assess the causes of non- performing loans related to banking operations

- To assess the causes of non- performing loans related to customers operations. 


\subsection{Research Question}

- Do bank- related causes contribute to non-performing loans?

- Do customers-related causes contribute to non-performing loans?

\section{Literature Review}

Among different types of risks that a bank faces in operating within the banking industry credit risk is one of the most influential risks that may force a bank to be bankrupt and credit risk is influenced by non-performing loans so it is necessary to consider the non-performing loans of a bank in determining the credit risk appropriately (Zelalem, 2010).

In other studies it has been shown that the bad economic conditions of a country influences the NPLs of the banking industry of the country and the main reason behind this kind of finding is that the bad economic condition affects the income of the clients of a bank and so they make delay of the repayments of the interests and principle amounts and in some cases fail to repay.

In some studies the relationship between NPLs and bank-specific factors has been clearly shown and so it can be said that the amount of non-performing loans of a specific bank is somewhat dependent on the effectiveness of the bank's policies, internal culture and efficiency of its employees.

Another study related to NPL conducted by Louzis (2012), showed that the amount of NPLs in Greek banking industry is significantly influenced by both the management quality of the banks and the macroeconomic forces of the country.

According to the study of Eurak (2013) which was based on the banking system of South Europe it was concluded that high interest rate, economic downturn and high inflation rate are the main reasons of higher non-performing loans in an economy and the study was also conducted based on 69 banks from ten different countries.

Other factors that influence the credit risk of a bank are the size, performance and solvency of the bank as these factors are influential to the non-performing loans of the bank.

Reddy (2014) argues that a bank with high level of NPLs is forced to incur carrying costs on nonincome yielding assets that not only strike at portability but also at the capital adequacy of a bank, and in consequence, the bank faces difficulties in augmenting capital resources.

Banik \& Das (2015) conclude that percentage of classified loan is increasing among commercial banks, the amount of percentage of classified loans (POCL) is higher in state owned commercial banks than that of private commercial banks.

Ulfat-Ara-Joya(2017) studies shows Spread and loan \& advances have together significant impact on classified loans in both state-owned commercial banks and first generation private commercial banks.

\section{Research Methodology}

SMEs loan customers tend to have more than one loan from different financial institutions which make it hard for them to make loan repayment timely, so this lead to non-performing loans.

Poor banking policy, other banking policy does not assure loan repayment by the SME's loan customers, so these kinds of policies lead to Non-performing loans due to the fact that banking policies especially credit policies when they are not conducive. Long banking queue in banking hall: this discourages SMEs loan customers in repaying their loans, due to the reason that they are required to spend long time in banking queue something which demoralizes customers and eventually nonperforming loans. 


\section{CONCEPTUAL FRAMEWORK}

Independent Variable
Dependent Variable

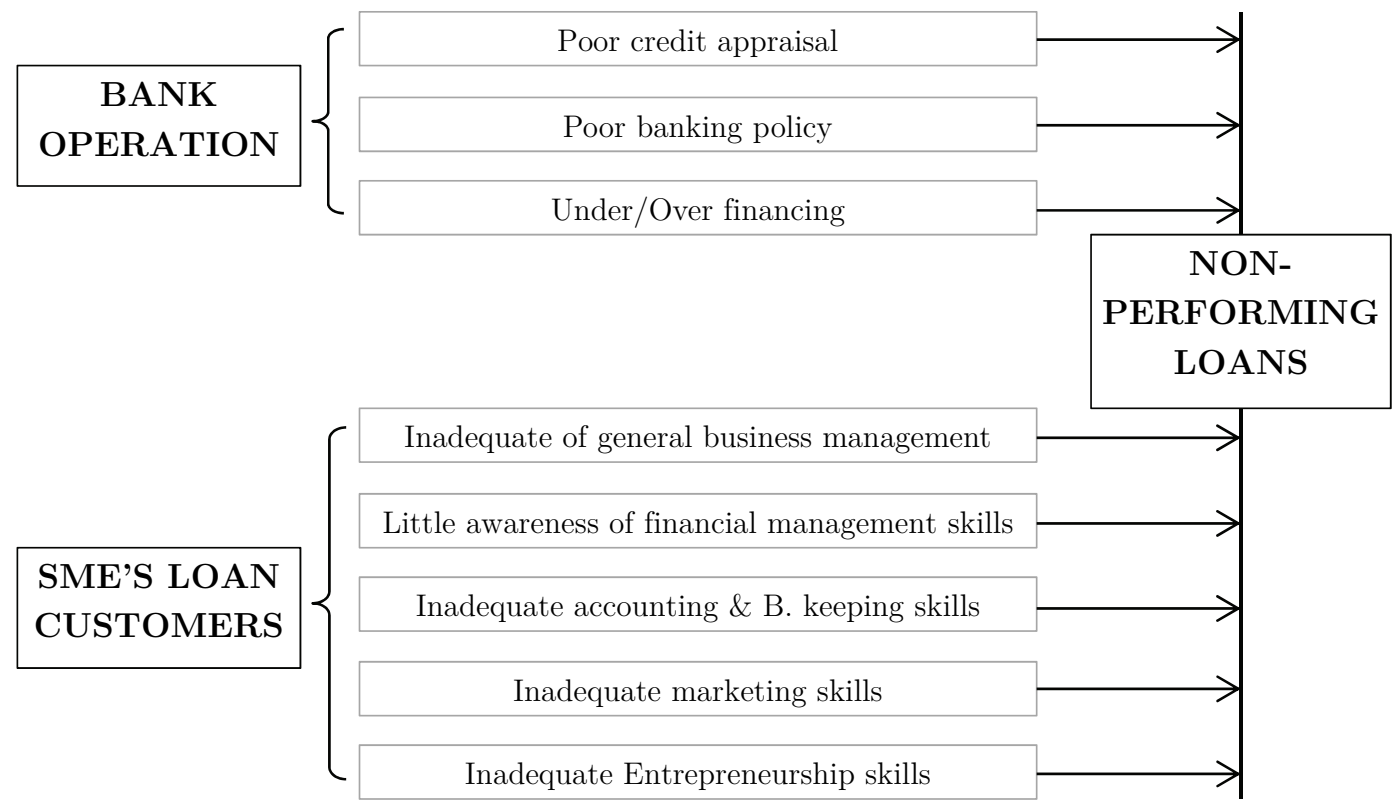

\subsection{Units of Study}

While it might true to Bangladesh commercial banks, this research study grouped non-performing loans factors into two groups: factors related to bank operations and factors relating to customers operations.

\subsection{Study Area}

The study was conducted on the public sector bank of Bangladesh as Sonali Bank Ltd, Agrani Bank Ltd., Rupali Bank Ltd., Janata Bank Ltd, BDBL, etc.

\subsection{Population of the Study}

The individual study population was drawn from the public sector banks of Bangladesh. According to Bangladesh Bank records of March 2017, SMEs customers were 1450. The banks branch has 6 Loan officers, 1 branch manager and 1 commercial manager and 2 officers from MNB court brokers.

\subsection{Sampling Frame}

The sampling frame was determined using assumptions which requires for the population below 100 units to take the whole population, $10 \%$ for the population above 100 but below 500 units, 20 percent for the population above 500 but below 100,00 units and 5 percent for the population above 100, 000 units.

\subsection{Sample Size}

Total sample size studied were 50 units as calculated above, where 10 were bank officers and 40 respondents were SME's loan customers of Bangladesh. 


\subsection{Sampling Technique}

The study employed random sampling where every participant had a chance to be included in the sample, where in the total number of 1450 SME's loan customers, 40 respondents were picked randomly by using the random number table.

\subsection{Data Collection Method}

Secondary data were collected from BANGLADESH BANK and SCBs published annual and quarterly reports, financial markets, businesses and governments annual reports, Bank of Bangladesh performance reports, Poverty related reports, National Surveys, SMEs customers credit files and other literature. The SMEs questionnaire included structured questions from which the interviewer noted down respondents' responses that best matched their views or experiences, giving inference on causes of nonperforming loans related to customers of SMEs loans.

\subsection{Quantitative Research Methodology}

To acquire data about reasons for nonperforming credits identified with banks and clients, quantitative approach was utilized, in light of the fact that most causes are very much reported by banks. Since the emphasis was on reasons for nonperforming credits, it was logical to begin with the study where a lot of general data was assembled towards the diverse causes. These concentration bunches particularly tended to reasons for nonperforming advances from bank and clients points of view. This consecutive outline was ruled by quantitative technique that went for surveying the variables causing non-performing advances. The examinations rank them and distinguish which cause contributes most and which cause contributes slightest.

\section{Regression analysis}

Model Summary

\begin{tabular}{|c|c|c|c|c|c|c|c|c|}
\hline Model & $\mathrm{R}$ & R Square & \multicolumn{3}{|c|}{ Adjusted R Square } & \multicolumn{3}{|c|}{ Std. Error of the Estimate } \\
\hline 1 & $.114^{\mathrm{a}}$ & .023 & \multicolumn{3}{|c|}{-.121} & \multicolumn{3}{|l|}{5.6443} \\
\hline \multicolumn{9}{|c|}{ ANOVA $^{b}$} \\
\hline Model & & \multicolumn{2}{|c|}{ Sum of Squares } & $\mathrm{DF}$ & \multicolumn{2}{|c|}{ Mean Square } & $\mathrm{F}$ & Sig. \\
\hline \multirow[t]{3}{*}{1} & Regression & 3.218 & & 1 & \multicolumn{2}{|c|}{3.219} & .103 & .787 \\
\hline & Residual & 260.381 & & 8 & \multicolumn{2}{|c|}{31.298} & & \\
\hline & Total & 243.600 & & 9 & & & & \\
\hline
\end{tabular}

Coefficients $^{\mathrm{a}}$

\begin{tabular}{llccccc}
\hline & & \multicolumn{4}{c}{ Standardized } \\
\multicolumn{1}{c}{ Unstandardized Coefficients } & Coefficients & \\
\hline Model & & $\mathrm{B}$ & Std. Error & Beta & $\mathrm{t}$ & Sig. \\
1 & (Constant) & 13.190 & 5.321 & & 2.479 & .037 \\
& general business management skills & 1.238 & 3.861 & .113 & .321 & .787 \\
\hline
\end{tabular}

Residuals Statistics ${ }^{\mathrm{a}}$

\begin{tabular}{lrrrrr}
\hline & Minimum & Maximum & Mean & Std. Deviation & $\mathrm{N}$ \\
\hline Predicted Value & 14.4286 & 15.6667 & 14.8000 & .59906 & 10 \\
Residual & -7.66667 & 4.59143 & .00000 & 5.28448 & 10 \\
Std. Predicted Value & -.631 & 1.449 & .000 & 1.000 & 10 \\
Std. Residual & -1.270 & .807 & .000 & .953 & 10 \\
\hline
\end{tabular}

a. Predictors: (Constant), general business management skills

b. Dependent Variable: Non-performing loans 
The table provides the $R$ and $R^{2}$ values. The $R$ value represents the simple correlation and is 0.113 , which indicates a low degree of correlation. The $R^{2}$ value indicates how much of the total variation in the dependent variable, gender, can be explained by the independent variable, female director. In this case, $.07 \%$ can be explained, which is very small.

Result: Here, the p-value (.757) is greater than 0.05, we accept the null hypothesis that there's difference between the means and conclude that a significant difference does not exist.

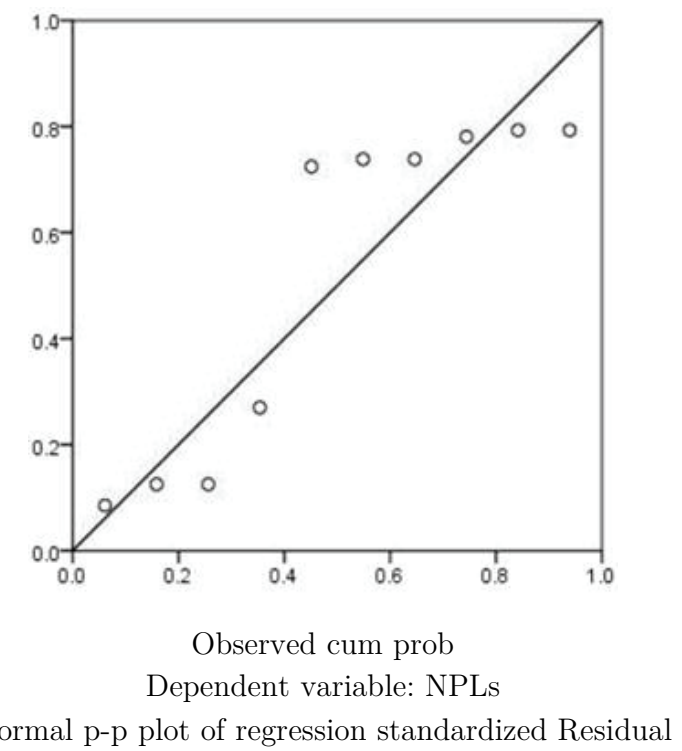

In the above regression standardized residual chart, the general business management skills control the chance of existence of non-performing loans in commercial banks and also the other independent variables are also positively correlated with the dependent variable that is non-performing loan.

\section{Discussion}

The objective of this study was to assess the causes of nonperforming loans related to bank and customer operations. The study found the following

\subsection{Causes of Non-Performing Loans Related to Customer Operations}

\section{General business management skills}

The result indicate that 8.5 percent had received training in general business management skills and the rest 91.5 percent they have never received training on general business management skills

\section{$>$ Financial management skills}

The result showed that 91.5 percent had never received training in financial management skills and 8.5 percent had received training in financial management skills.

\section{$>$ Accounting and book- keeping skills}

Result showed that only 16 percent had received training of accounting and book keeping skills. 84 percent did never receive accounting and book keeping skills.

\section{$>$ Sales and marketing skills}

Field response showed that 8.5 percent had received training of sales and marketing skills and 91 percent had never received service of awareness on sales and marketing skills.

\section{> Entrepreneurship skills}

Result showed that 25 percent they received service of awareness of Entrepreneurship skills, 75 percent they have never received services of awareness of entrepreneurship skills.

\section{$>$ Transport services skills}

90 percent respondents had received training on transport services skill, while the rest 10 percent had never received training on transport services skills 


\subsection{Causes of NPLs Related to Bank Operations}

The result for 10 bank officers interviewed about cause of non-performing loans related to bank operation were 30 percent Fund diversion, 30 percent poor credit appraisal, 20 percent frauds from bank officers, 10 Percent competition from other institutions and 10 percent long queue in banking hall.

\section{Conclusion}

Credits shape $80 \%$ part of the aggregate resources in business banks in Bangladesh. These benefits produce enormous premium salary for banks which to a substantial degree decides the budgetary execution of banks. Be that as it may, some of these advances as a rule fall into non-performing status and antagonistically influence the execution of banks. This is on the grounds that non-performing advances can influence the capacity of banks to assume their part in the improvement of the economy.

Discoveries showed that non-performing advances in business Banks are caused by the two elements identified with bank tasks and factors identified with clients activities. Elements identified with bank task recognized were poor credit evaluation, poor credit strategy, cheats from bank authorities, rivalry from other monetary foundations and long line in managing an account lobbies.

Variables identified with clients activities distinguished are insufficient general business administration aptitudes, lacking of monetary administrations abilities, and deficient bookkeeping and accounting aptitudes.

\section{Recommendation}

The study, based on the findings mentioned above recommends the following in order to mitigate causes of nonperforming loans

\subsection{Causes NPLs related to Bank Operation}

Bank should have adequate and reliable information about clients, good credit policy, conduct appropriate credit appraisal, and train their customers on business, management, financial, entrepreneurships and book keeping skills.

\subsection{Causes of NPLs related to Customer Operation}

For the case of non-performing loans related to customers operations loan customers should be trained on different business skills like the General business management skills, financial services skills, and Accounting and book keeping skills. These will facilitate smoothly operations of business activities on their side.

\subsection{Area of Further Study}

The study recommends further studies to:

Relationship between business management skills and nonperforming loans:

In this case the researcher should investigate clearly on how business management skills can lead to non-performing loans, which is how far does business management skills influence the performing loans. The relationship between credit policy and non-performing loans:

$>$ In this case, further researchers should show deeply how non-performing loans can be caused by credit policy as long as it is through the credit policies of the bank which govern the credit issues. Effects of nonperforming loans on bank performance

$>$ A clear assessment of the effects of non-performing loans to bank performance should be researched by the further researchers.

$>$ The contribution of nonperforming loans on financial crisis

$>$ In this case the researcher should assess the contribution of non-performing loans to the financial crisis 
Risk management of nonperforming loans.

Further research should be conducted on how non-performing loans as a risk should be managed.

\section{References}

1. AdhikaryBishnu Kumar, "Nonperforming Loans in the Banking Sector in Bangladesh: Realities and Challenges" page- $75-90$

2. B karica( 2013) [online] Available at: http://hrcak.srce.hr/file/201674 [Accessed 14 Aug. 2017].

3. Bangladesh Bank Annual Report 2012-2013

4. Banking Sector: Current Status Bangladesh Economic Update December 2013.

5. Carey, M.,(1998). Credit risk in private debt portfolios. Journal of Finance 53, 1363-1387.

6. Jimenez, G., Salas, V. and Saurina, J., (2006). Determinants of collateral.Journal of financial economics, 81(2), pp. $255-281$.

7. Lata Rabeya Sultana et ad.(2013) "Nonperforming loan: A Detriment to sound environment in banking industry" The Daily Sun, July.

8. Louzis, D., Vouldis,A. and Metaxas,V. (2012). Macroeconomic and bank-specific determinants of non-performing loans in Greece: A comparative study of mortgage, business and consumer loan portfolios. Journal of Banking \& Finance, 36(4), pp.1012-1027.

9. Makri, V., Tsagkanos, A. and Bellas, A. (2014). Determinants of non-performing loans: The case of Eurozone. Panoeconomicus, 61(2), pp.193-206.

10. Masoom Mohammad.et al.(2013) "Strategies for recovery of nonperforming loan", The Financial Express,16 February.

11. Mishkin Frederic S. (2011) Financial Markets and Institutions (6th Addition) India Dorling Kindersley (India) PVT. Ltd

12. Rahman QaziMahmudur. et al(2012), "All about Non-performing Loans: The Bangladesh Scenario" The Financial Express, November.

13. Rahman, R. (2017). Default loans soar. [online] The Daily Star. Available at: http://www.thedailystar.net/ frontpage/default-loans-soar-1275622 [Accessed 7 Aug. 2017]. Rashid Mamunet al(2012) "Debt Default in Banks" Bank Parikrama

14. Zelalem. (2013). Determinants of Non-Performing Loans in Licensed Commercial Banks: Evidence from Ethiopian Banks. Asian Economic and Financial Review, 5(6), pp.868-882. 